\title{
Impact of Cross- and Self-pollination on Fruit Set, Fruit Size, Seed Number, and Harvest Timing Among 13 Southern Highbush Blueberry Cultivars
}

\author{
Sarah K. Taber and James W. Olmstead ${ }^{1}$
}

\begin{abstract}
ADDITIONAL INDEX WORDS. Vaccinium corymbosum, blueberry breeding, self-incompatibility

Summary. Cross-pollination has been associated with improved fruit set, weight, and shortened time to ripening in southern highbush blueberry [SHB (Vaccinium corymbosum interspecific hybrids)]. Because of this, growers commonly plant two or more cultivars in small blocks to facilitate cross-pollination. However, many SHB cultivars may vary in the degree of improvement in each parameter after crosspollination. Understanding the impacts of cross-pollination on a particular cultivar is crucial to forming planting recommendations, particularly as growers begin to transition to fields designed for machine harvest where large solid blocks would increase the harvest efficiency. The objective of this study was to examine the effects of cross- and self-pollination among 13 commonly planted or newly released SHB cultivars. Cross-pollination typically improved fruit set, fruit weight, and seed number while decreasing the average days to harvest. Cross-pollinated fruit always weighed more than self-pollinated fruit from the same cultivar, which was highly correlated to seed number per fruit. Although there was variation for each trait, interplanting with another unrelated cultivar sharing a similar bloom time remains the best recommendation to ensure early, high yield among these SHB cultivars.
\end{abstract}

A lthough cultivated SHB are typically capable of setting fruit when self-pollinated, growers commonly plant multiple cultivars to enhance cross-pollination (Williamson et al., 2015). This recommendation is based on previous research describing the benefits of cross-pollination among cultivated blueberry species. Cross-pollination has typically been associated with improved fruit set in northern highbush blueberry $[V$. corymbosum (Bailey, 1938; Coville, 1921; Dogterom et al., 2000; Ehlenfeldt, 2001; MacKenzie, 1997; Meader and Darrow, 1947; Miller et al., 2011; Morrow, 1943)], rabbiteye blueberry [Vaccinium virgatum (Darnell and Lyrene, 1989; El-Agamy et al., 1981; Gupton and Spiers, 1994; Meader and Darrow, 1944; Payne et al., 1989)], lowbush (Vaccinium angustifolium) and half-high blueberry $(V$. corymbosum $\times V$. angustifolium

Horticultural Sciences Department, University of Florida, 2211 Fifield Hall, Gainesville, FL 32611

The authors gratefully acknowledge the field and greenhouse support and assistance of David Norden and Werner Collante, and statistical consulting by Mihai Giurcanu.

${ }^{1}$ Corresponding author. E-mail: jwolmstead@ufl.edu. hybrids) (Aalders and Hall, 1961; Harrison et al., 1994; Rabaey and Luby, 1988; Wood, 1968), and SHB (Chavez and Lyrene, 2009; El-Agamy et al., 1981; Gupton and Spiers, 1994; Lyrene, 1989). In contrast, greater fruit set in a cultivar after self-pollination compared with cross-pollination has been observed infrequently and has often been attributed to reduced compatibility with the pollen source used for cross-pollination (Ehlenfeldt, 2001; Gupton, 1984; Lang and Danka, 1991; White and Clark, 1939).

Greater fruit size and/or a shorter fruit development period with crosspollination compared with selfpollination has been documented in northern highbush, rabbiteye, lowbush, half-high, and SHB cultivars (Chavez and Lyrene, 2009; Ehlenfeldt, 2001; Gupton, 1984; Gupton and Spiers, 1994; Lang and Danka, 1991; Lyrene, 1989; MacKenzie, 1997; Meader and Darrow,
1944, 1947; Morrow, 1943; Payne et al., 1989; Rabaey and Luby, 1988; Wood, 1968). In these studies, an increase in the number of fully developed seeds was associated with the increase in fruit size and shorter fruit development period. Supporting this association between seed number and fruit size and development period are cases where interspecific crosses have been compared with crosses that were either self- or cross-pollinated. Aalders and Hall (1961) found reduced seed set in lowbush $\times$ velvetleaf blueberry (Vaccinium myrtilloides) crosses that resulted in smaller fruit size and later ripening compared with intraspecific lowbush crosses. Similarly, Gupton and Spiers (1994) found that SHB cultivars pollinated with rabbiteye pollen had reduced fruit weight, but no significant difference in fruit development period compared with intraspecific SHB crosses. Among intraspecific northern highbush crosses, Ehlenfeldt (2001) regressed fruit size and ripening time measurements on total seed number and found the weight of 'Rubel' was not impacted by seed number.

The degree to which earliness and yield are improved by crosspollination is an important consideration when forming planting recommendations for SHB. Early fruit maturity is a critical factor for the SHB industry, as growers rely on the high-value marketing period between the conclusion of southern hemisphere fresh blueberry imports and onset of harvest in traditional U.S. production regions. Therefore, current recommendations suggest including multiple cultivars for cross-pollination in all new SHB plantings. However, larger singlecultivar fields are easier to manage, particularly for some of the common cultural practices necessary for production in subtropical regions (e.g., timing and rate of hydrogen cyanamide application), and would be desirable for mechanical harvest.

The objective of this study was to compare the effects of cross- and

\begin{tabular}{llll}
\hline $\begin{array}{l}\text { Units } \\
\text { To convert U.S. to SI, } \\
\text { multiply by }\end{array}$ & U.S. unit & SI unit & $\begin{array}{l}\text { To convert SI to U.S., } \\
\text { multiply by }\end{array}$ \\
\hline 3.7854 & gal & $\mathrm{L}$ & 0.2642 \\
28.3495 & $\mathrm{OZ}$ & $\mathrm{g}$ & 0.0353 \\
$\left({ }^{\circ} \mathrm{F}-32\right) \div 1.8$ & ${ }^{\circ} \mathrm{F}$ & ${ }^{\circ} \mathrm{C}$ & $\left({ }^{\circ} \mathrm{C} \times 1.8\right)+32$
\end{tabular}


self-pollination on fruit set, fruit size, seed number, and time to reach berry maturity among new and traditional SHB cultivars.

\section{Materials and methods}

Plant material. Thirteen cultivars were evaluated for 2 years in the trial, including current commercial standards (Emerald and Jewel), newer cultivars increasing in acreage (Farthing, Scintilla, and Sweetcrisp), and new cultivar releases that have yet to be planted in significant acreage [FL03-291 (Bobolink ${ }^{\text {TM }}$, FL04-235 (Chickadee ${ }^{\text {TM }}$ ), FL96-43 (Flicker $^{\mathrm{TM}}$ ), FL98-325 (Indigocrisp ${ }^{\mathrm{TM}}$ ), FL02-40 (Kestrel ${ }^{\mathrm{TM}}$ ), FL01-173 (Meadowlark ${ }^{\mathrm{TM}}$ ), FL05-627 (Raven ${ }^{\mathrm{TM}}$ ), and FL05-107 (Vireo $\left.{ }^{\mathrm{TM}}\right)$ ]. The trademarked name of these recent releases will be used subsequently in this manuscript. On 15 Dec. 2011, a single, field-grown, 3-year-old plant of each cultivar was transplanted into a 10-gal container (No. 10 Olympic; BWI Companies, Nash, TX) using $100 \%$ peatmoss as a substrate (Black Bale; Lambert, Rivière-Ouelle, QC, Canada), and placed into a cooler at $40{ }^{\circ} \mathrm{F}$. On 6 Feb. 2012, after $1200 \mathrm{~h}$ of chilling (less than $45^{\circ} \mathrm{F}$ ), all plants were moved to a greenhouse to exclude pollinating insects. The high temperature limit was $78{ }^{\circ} \mathrm{F}$ and a low temperature limit was $45^{\circ} \mathrm{F}$. In the second year, plants were removed from the field on 2 Jan. 2013 and chilled in a cooler for over $700 \mathrm{~h}$ of chilling and moved to a greenhouse under the same conditions on 1 Feb. 2013. Upon moving to the greenhouse, multiple branches were marked for cross- or self-pollination, with about half of each plant designated for use as cross- or selfpollination treatments. All flowers that were already open at the beginning of the experiment were removed, and adventitious shoots and other excess growth were pruned to facilitate pollination. Potted plants were watered daily as needed and fertilized every 2 weeks with $20 \mathrm{~N}-8.7 \mathrm{P}-16.6 \mathrm{~K}$ watersoluble fertilizer with micronutrients (Scotts, Marysville, $\mathrm{OH}$ ).

Suitable plants for 'Jewel', 'Scintilla', and 'Vireo' were not available for pollination in 2013. There were insufficient flowers available on the plants of 'Chickadee' and 'Bobolink' in 2012 and 2013, respectively, so only self-pollinations were performed to assess the cultivar. Similarly, flowers from 'Flicker' in 2013 did not shed sufficient pollen for self-pollinations.

POllination AND FRUit HARVEST. The same pollen source was used for all cross-pollinations within a year. The criteria for choosing the pollen source included sufficient flower density and bloom overlap to provide pollen for over 1500 pollinations, and no common parent or grandparent with any of the cultivars to be tested. FLl1-037 and FL04-232 were the SHB selections used for cross-pollination in 2012 and 2013, respectively. Pollinations were performed daily through the month of February until 120 flowers for each pollination type (cross and self) for each cultivar were pollinated. All flowers used as the female pollen recipients, regardless of cross- or selfpollination, were emasculated before pollination. All flowers in each cluster were not pollinated, but those flowers not pollinated were removed from each cluster. Transfer of pollen to the stigma of each flower was made immediately after all flowers used for pollination were emasculated. Pollination was performed by removing a fresh flower from the designated pollen parent, rolling it between the fingers to release pollen onto a thumbnail, and contacting the pollenloaded thumbnail to the stigma of the receiving flower. Hands were washed between pollinations. This methodology is routinely used within the University of Florida blueberry breeding program. For self-pollination, a suitable dehiscent flower from the same potted plant was used.

In 2012, fruit were harvested every $\mathrm{l}$ to $3 \mathrm{~d}$ depending on presence of completely blue fruit. In 2013, berries were collected every $4 \mathrm{~d}$. In both years, all fruit resulting from 120 cross- and self-pollinations of each cultivar were weighed immediately after harvest on an analytical scale (CP224S; Sartorius Corp., Bohemia, $\mathrm{NY}$ ) and stored at $-4{ }^{\circ} \mathrm{F}$ until seed counting. Seed number per berry was determined by slicing each berry in half with a razor blade and removing viable seeds [distinguishable from placenta and aborted seeds by size, plumpness (aborted often appear shriveled), and dark tan/brown color] from the surrounding pulp via forceps.
Statistical analysis. Single plants were used to calculate fruit set and time to achieve maturity (number of days from median pollination to median harvest times). The statistical analysis for the seed data was performed using a four factor full factorial linear model, with seed number as the response variable and year, pollination type, cultivar, and harvest period (calculated as four periods representing the fruit harvested at $<50,51-60,61-70$, and $>70 \mathrm{~d}$ after median pollination date) as fixed explanatory factors. The statistical analysis for the fruit weight data was performed using a four-factor full factorial analysis of covariance model, with weight as a response variable, the same four factorial treatment structure as for the seed number data, and interactions between seed number and cultivars and between seed number and harvest period for the linear effects of seed number on fruit weight. To prevent over-parametrization of the model, we chose only these two-way interactions; in this way, we expected to increase the precision of the linear effects estimates at the expense of a decrease in the accuracy of the estimates.

Data analysis was performed using SAS/GLIMMIX software (SAS version 9.3; SAS Institute, Cary, NC). Main effects and two-, three-, and four-way interaction effects were included in the linear models. Because the data set was unbalanced, some interaction effects and adjusted least-squares means were nonestimable. However, we estimated the unadjusted least-squares means using the "bylevel" key word in the lsmeans statement of SAS/GLIMMIX. The significance of the main effects, two-, three-, and four-way interaction effects were tested using the type III F-tests for fixed effects and mean separation for the significant main and interaction effects in the model were performed using Tukey's multiple comparison procedures using the letter grouping given by the "lines" key word of the SAS's lsmeans statement. The slice statement was used where appropriate to further explore significant interactions. Because the year main effect was significantly different $(P<0.05)$ for both seed number and fruit weight, each year was analyzed separately to reduce higher order interactions. 


\section{Results and discussion}

Fruit set was generally similar or greater with cross-pollinated flowers than self-pollinated flowers in both years of the study (Table 1). In 2012, 'Bobolink', 'Flicker', 'Indigocrisp', and 'Kestrel' had lower fruit set after cross-pollination than selfpollination. Although comparison could not be made for 'Bobolink' or 'Flicker', both 'Indigocrisp' and 'Kestrel' had higher fruit set after cross-pollination in 2013. Cultivar

Table 1. Fruit set of 13 potted, greenhouse-grown southern highbush blueberry cultivars after cross- and self-pollination in 2012 and 2013. Canes on single plants were divided between cross- or self-pollination treatments, and 120 individual flowers were hand-pollinated for each treatment on each cultivar.

\begin{tabular}{|c|c|c|c|c|}
\hline \multirow[b]{3}{*}{ Cultivar } & \multicolumn{4}{|c|}{ Fruit set (\%) } \\
\hline & \multicolumn{2}{|c|}{2012} & \multicolumn{2}{|c|}{2013} \\
\hline & Cross $^{z}$ & Self & Cross & Self \\
\hline Bobolink & 66.7 & 71.0 & $-^{y}$ & 42.5 \\
\hline Chickadee & - & 42.6 & 55.5 & 46.4 \\
\hline Emerald & 78.0 & 68.1 & 65.7 & 26.7 \\
\hline Farthing & 89.1 & 75.7 & 49.6 & 51.1 \\
\hline Flicker & 45.5 & 81.2 & 30.8 & - \\
\hline Indigocrisp & 62.4 & 92.8 & 91.8 & 52.5 \\
\hline Jewel & 52.4 & 35.7 & - & - \\
\hline Kestrel & 54.6 & 75.3 & 83.5 & 43.1 \\
\hline Meadowlark & 55.4 & 18.3 & 51.1 & 39.6 \\
\hline Raven & 100.0 & 28.1 & 38.7 & 28.0 \\
\hline Scintilla & 42.6 & 32.1 & - & - \\
\hline Sweetcrisp & 15.1 & 9.0 & 44.2 & 32.8 \\
\hline Vireo & 63.6 & 34.6 & - & - \\
\hline
\end{tabular}

${ }^{2}$ Cross-pollination was performed with the selections FL11-037 and FL04-232 in 2012 and 2013, respectively. y Data not available.

Table 2. Fruit development period (number of days from median pollination date to median harvest date) of 13 potted, greenhouse-grown southern highbush blueberry cultivars after cross- and self-pollination in 2012 and 2013. Canes on single plants were divided between cross- or self-pollination treatments, and 120 individual flowers were hand-pollinated for each treatment on each cultivar.

\begin{tabular}{|c|c|c|c|c|}
\hline \multirow[b]{3}{*}{ Cultivar } & \multicolumn{4}{|c|}{ Fruit development period $(\mathrm{d})$} \\
\hline & \multicolumn{2}{|c|}{2012} & \multicolumn{2}{|c|}{2013} \\
\hline & Cross $^{\mathrm{z}}$ & Self & Cross & Self \\
\hline Bobolink & 40 & 36 & $\smile^{\mathrm{y}}$ & 42 \\
\hline Chickadee & - & 54 & 48 & 60 \\
\hline Emerald & 51 & 50 & 52 & 64 \\
\hline Farthing & 46 & 48 & 38 & 42 \\
\hline Flicker & 60 & 53 & 44 & - \\
\hline Indigocrisp & 45 & 56 & 46 & 46 \\
\hline Jewel & 54 & 54 & - & - \\
\hline Kestrel & 47 & 47 & 57 & 67 \\
\hline Meadowlark & 44 & 47 & 53 & 73 \\
\hline Raven & 54 & 44 & 71 & 43 \\
\hline Scintilla & 50 & 53 & - & - \\
\hline Sweetcrisp & 51 & 52 & 45 & 62 \\
\hline Vireo & 56 & 50 & - & - \\
\hline
\end{tabular}

${ }^{\mathrm{z}}$ Cross-pollination was performed with the selections FL11-037 and FL04-232 in 2012 and 2013, respectively. yata not available. difficult to determine the degree to which maternal plant resource differences contributed to the yearly variation, and should be explored in future studies.

There was a general trend of a shorter fruit development period (as calculated by the number of days between the median pollination date and median harvest date for each cross- and self-pollination treatment for each cultivar) among cross-pollinated flowers when compared with their self-pollinated counterparts in both years (Table 2 ). The only cultivar to consistently fruit earlier when self-pollinated was Raven. The effect of pollination treatment on fruit development period was also evident when the percentage of total fruit weight harvested from each treatment was split into four artificial "harvest periods" (Fig. 1). When separated in this manner, the percent of total harvest weight that was harvested in the latter half of the season was markedly increased after self-pollination, in a period often defined by declining prices in southeastern blueberry production.

All main effects were significant $(P<0.05)$ (cultivar, pollination type, and harvest period), as well as twoand three-way interactions for fruit weight in 2012. Significant differences were also found among all main effects except the pollination type in 2013. The significant cultivar by pollination type interaction indicated that cross-pollination resulted in significantly greater fruit weight of individual berries $(P<0.05)$ in nearly all cases (Table 3 ). Where fruit weight was not significantly different in first year and was re-evaluated in the second year (i.e., 'Farthing' and 'Meadowlark'), the difference between cross- and self-pollination was significantly different in the second year. To determine the difference in fruit weight among cultivars and pollination types in each harvest period, the significant three-way interaction of cultivar, pollination type, and harvest period was sliced by harvest period (Tables 4 and 5). Again, the general trend was for greater fruit weight in cross-pollinated fruit from each cultivar.

Seed number was significantly different $(P<0.05)$ for cultivar, pollination type, harvest period, and all the interactions between these main 


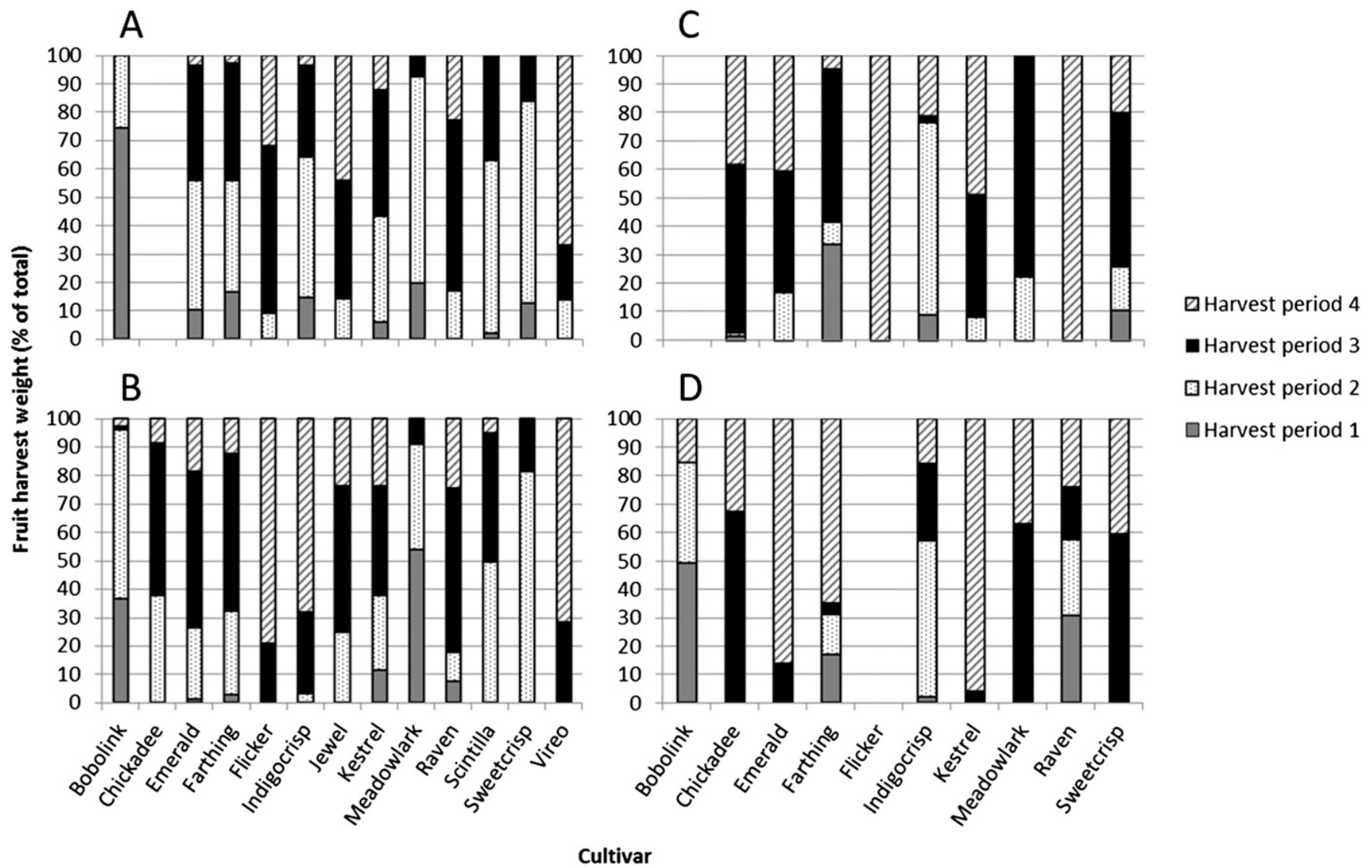

Fig. 1. Percent of total fruit harvested from 13 southern highbush blueberry cultivars in 2012 (A, B) and 2013 (C, D) after cross (A, C) and self-pollination $(\mathrm{B}, \mathrm{D})$. Harvest periods $1,2,3$, and 4 were $<50,51-60,61-70$, and $>0 \mathrm{~d}$ after median pollination date, respectively.

Table 3. Average fruit weight of 13 southern highbush blueberry cultivars after cross- and self-pollination in 2012 and 2013. Mean values calculated from 120 individual hand-pollinations using cross- or self-pollen made on 3 -year-old potted plants in a greenhouse.

\begin{tabular}{lcccccc}
\hline & \multicolumn{7}{c}{ Avg fruit wt $(\mathrm{g})^{\mathrm{z}}$} \\
\cline { 2 - 7 } Cultivar & Cross $^{\mathrm{y}}$ & Self & Significance $^{\mathrm{x}}$ & Cross & Self & Significance \\
\hline Bobolink & 1.67 & 1.4 & $*$ & $-{ }^{\mathrm{w}}$ & 1.15 & \\
Chickadee & - & 1.73 & & 1.49 & 1.4 & NS \\
Emerald & 1.92 & 1.52 & $*$ & 1.86 & 1.67 & NS \\
Farthing & 2.17 & 2.06 & $\mathrm{NS}$ & 1.94 & 1.11 & $*$ \\
Flicker & 1.52 & 1.19 & $*$ & 1.38 & - & \\
Indigocrisp & 1.52 & 1.22 & $*$ & 1.81 & 1.35 & $*$ \\
Jewel & 1.52 & 1.39 & $\mathrm{NS}$ & - & - & \\
Kestrel & 1.91 & 1.52 & $*$ & 1.4 & 1.16 & $*$ \\
Meadowlark & 1.64 & 1.62 & $\mathrm{NS}$ & 1.85 & 1.06 & $*$ \\
Raven & 2.63 & 1.95 & $*$ & 1.15 & 0.71 & $*$ \\
Scintilla & 1.87 & 1.52 & $*$ & - & - & \\
Sweetcrisp & 0.91 & 0.67 & $*$ & 1.44 & 1.12 & $*$ \\
Vireo & 1.72 & 1.39 & $*$ & - & - & \\
\hline
\end{tabular}

${ }^{\mathrm{z}} 1 \mathrm{~g}=0.0353 \mathrm{oz}$.

${ }^{y}$ Cross-pollination was performed with pollen from the selections FL11-037 and FL04-232 in 2012 and 2013, respectively. ${ }^{\mathrm{x}}$ Asterisk $\left({ }^{*}\right)$ or Ns indicates significant or nonsignificant differences between cross- and self-pollination adjusted means at $P \leq$ 0.05 .

"Data not available.

effects in both years. Slicing the cultivar by pollination type interaction showed that the only cases where self- pollination led to a significant increase in seed number were for Kestrel in 2012 and Raven in 2013
(Table 6). Similar to fruit set, it may be possible that the pollen sources used for cross-pollination (FLl 1-037 and FL04-232 in 2012 and 2013, respectively) may have had some level of incompatibility with 'Kestrel' and 'Raven'. Since there was no consistent trend for either cultivar, it is unlikely that either Kestrel or Raven have a higher than normal degree of selfcompatibility. Overall, seed number per fruit was lower for both cross- and self-pollination than in previously reported studies with northern highbush and rabbiteye blueberries (Ehlenfeldt, 2001; Gupton and Spiers, 1994; MacKenzie, 1997), but similar to those observed by El-Agamy et al. (1981) when testing similar Florida SHB germplasm. We were also very conservative in determining fully-formed seed, and thus may have reduced the overall seed count in the present study by identifying some that could have germinated as aborted based on shriveled appearance. In the present study, pollen load was not measured for each pollination, and we cannot rule out 
Table 4. Average fruit weight of 13 southern highbush blueberry cultivars during four different harvest periods in 2012 following cross- and self-pollination. Mean values calculated from 120 individual hand-pollinations using cross- or self-pollen made on 3-year-old potted plants in a greenhouse.

\begin{tabular}{|c|c|c|c|c|c|c|c|c|c|c|c|c|}
\hline \multirow[b]{3}{*}{ Cultivar } & \multicolumn{12}{|c|}{ Avg fruit wt $(g)^{\mathrm{z}}$} \\
\hline & \multicolumn{3}{|c|}{ Harvest period $1^{y}$} & \multicolumn{3}{|c|}{ Harvest period 2} & \multicolumn{3}{|c|}{ Harvest period 3} & \multicolumn{3}{|c|}{ Harvest period 4} \\
\hline & Cross $^{x}$ & Self & Significance $^{\mathrm{w}}$ & Cross & Self & Significance & Cross & Self & Significance & Cross & Self & Significance \\
\hline Chickadee & $-^{\mathrm{v}}$ & 0.00 & & - & 1.92 & & - & 1.62 & & - & 0.32 & \\
\hline Emerald & 2.03 & 0.52 & * & 2.13 & 2.16 & NS & 1.96 & 1.47 & * & 0.34 & - & \\
\hline Farthing & 2.26 & 1.46 & * & 2.49 & 2.38 & NS & 2.37 & 2.26 & NS & 0.33 & 1.27 & * \\
\hline Jewel & - & - & & 1.73 & 1.69 & NS & 1.49 & 1.81 & NS & 0.56 & 0.82 & NS \\
\hline Kestrel & 1.04 & 2.47 & * & 2.04 & 2.51 & * & 1.63 & 2.00 & NS & 0.66 & 1.32 & * \\
\hline Meadowlark & 1.90 & 2.67 & * & 1.89 & 1.86 & NS & - & - & & - & - & \\
\hline Raven & - & 0.58 & & 3.12 & 0.69 & * & 3.09 & 2.48 & * & 2.22 & 2.01 & NS \\
\hline Scintilla & 0.58 & - & & 2.31 & 1.88 & * & 2.05 & 1.53 & * & - & 0.43 & \\
\hline Sweetcrisp & 0.55 & - & & 1.45 & 1.23 & NS & - & - & & - & - & \\
\hline
\end{tabular}

${ }^{\mathrm{z}} 1 \mathrm{~g}=0.0353 \mathrm{oz}$.

y Harvest periods $1,2,3$, and 4 were $<50,51-60,61-70$, and $>70 \mathrm{~d}$ after median pollination date, respectively.

${ }^{x}$ Cross-pollination was performed with pollen from the selections FLl1-037 and FL04-232 in 2012 and 2013, respectively.

"Asterisk $\left({ }^{*}\right)$ or Ns indicates significant or nonsignificant differences between cross- and self-pollination adjusted means at $P \leq 0.05$.

"Data not available.

Table 5. Average fruit weight of 13 southern highbush blueberry cultivars during four different harvest periods in 2013 following cross- and self-pollination. Mean values calculated from 120 individual hand-pollinations using cross- or self-pollen made on 3-year-old potted plants in a greenhouse.

\begin{tabular}{|c|c|c|c|c|c|c|c|c|c|c|c|c|}
\hline \multirow[b]{3}{*}{ Cultivar } & \multicolumn{12}{|c|}{$\operatorname{Avg}$ fruit wt $(g)^{z}$} \\
\hline & \multicolumn{3}{|c|}{ Harvest period $1^{y}$} & \multicolumn{3}{|c|}{ Harvest period 2} & \multicolumn{3}{|c|}{ Harvest period 3} & \multicolumn{3}{|c|}{ Harvest period 4} \\
\hline & Cross $^{x}$ & Self & Significance $^{w}$ & Cross & Self & Significance & Cross & Self & Significance & Cross & Self & Significance \\
\hline Chickadee & - & - & 一 & 1.13 & 1.50 & NS & 1.80 & 1.69 & NS & 1.24 & 1.08 & NS \\
\hline Emerald & - & - & & 1.95 & - & & 2.35 & 2.15 & NS & 1.56 & 1.77 & NS \\
\hline Farthing & 2.07 & 1.38 & * & 1.52 & 1.13 & NS & 2.11 & 0.67 & * & 1.26 & 1.10 & NS \\
\hline Kestrel & - & - & & 1.53 & - & & 1.67 & 1.00 & * & 1.18 & 1.24 & NS \\
\hline Meadowlark & - & - & & 2.45 & - & & 1.94 & - & & - & 1.19 & \\
\hline Raven & - & 1.42 & & - & 1.37 & & - & 0.96 & & 1.22 & 0.90 & NS \\
\hline Sweetcrisp & 1.45 & - & & 2.04 & - & & 1.63 & 1.61 & NS & 0.94 & 0.87 & NS \\
\hline
\end{tabular}

${ }^{\mathrm{z}} 1 \mathrm{~g}=0.0353 \mathrm{oz}$

${ }^{y}$ Harvest periods $1,2,3$, and 4 were $<50,51-60,61-70$, and $>70 \mathrm{~d}$ after median pollination date, respectively.

${ }^{x}$ Cross-pollination was performed with pollen from the selections FL11-037 and FL04-232 in 2012 and 2013, respectively.

"Asterisk $\left(^{*}\right)$ or Ns indicates significant or nonsignificant differences between cross- and self-pollination adjusted means at $P \leq 0.05$.

'Data not available.

the possibility that some flowers received less pollen than others. However, it was assumed that more than sufficient numbers of pollen tetrads were deposited on each stigma to facilitate as complete of fertilization as possible. Dogterom et al. (2000) indicated that excess pollen load did not result in fertile seeds equal to the number of ovules present at fertilization, and that excess pollen did not result in an increase in fruit set, fruit weight, or time to ripening.

The predominant explanation associating cross-pollination to higher yield in blueberries is that crosspollination increases the number of viable seeds. This indirectly increases fruit size by affecting levels of gibberellic acids and/or other hormones (Barker and Collins, 1965; Brewer and Dobson, 1969; El-Agamy et al., 1982; Meader and Darrow, 1944; Moore et al., 1972). In light of this, we used seed number as a covariate in our analyses of fruit weight differences. The present results are consistent with previous work showing that the influence of seed number on fruit size varied widely by cultivar (Bailey, 1938; Brewer and Dobson, 1969; Darrow, 1958; El-Agamy et al., 1982; Gupton, 1984; Harrison et al., 1994; Knight and Scott, 1964; Lyrene and Goldy, 1983; Meader and Darrow, 1944 , 1947; Rabaey and Luby, 1988; White and Clark, 1939).

Pollenizer compatibility among blueberries follows a spectrum from full to partial to complete incompatibility between any two given parents. The exact mechanism for this effect remains unknown. However, it appears to follow a general trend of 
Table 6. Average number of seeds per fruit of 13 southern highbush blueberry cultivars after cross- and self-pollination.

\begin{tabular}{|c|c|c|c|c|c|c|}
\hline \multirow[b]{3}{*}{ Cultivar } & \multicolumn{6}{|c|}{ Avg seeds (no./fruit) } \\
\hline & \multicolumn{3}{|c|}{2012} & \multicolumn{3}{|c|}{2013} \\
\hline & Cross $^{\mathrm{z}}$ & Self & Significance $^{\mathrm{y}}$ & Cross & Self & Significance \\
\hline Bobolink & 12.8 & 6.1 & * & $-^{x}$ & 20.4 & \\
\hline Chickadee & - & 5.0 & & 4.1 & 2.6 & NS \\
\hline Emerald & 14.9 & 7.2 & * & 7.0 & 2.9 & * \\
\hline Farthing & 27.7 & 12.6 & * & 13.0 & 2.8 & * \\
\hline Flicker & 20.4 & 8.0 & * & 6.1 & - & \\
\hline Indigocrisp & 7.6 & 6.6 & NS & 12.4 & 4.3 & * \\
\hline Jewel & 3.3 & 4.1 & NS & - & - & \\
\hline Kestrel & 11.5 & 17.2 & * & 16.3 & 10.4 & * \\
\hline Meadowlark & 8.5 & 11.9 & NS & 19.7 & 7.9 & * \\
\hline Raven & 9.0 & 3.6 & * & 2.9 & 8.8 & * \\
\hline Scintilla & 8.6 & 9.2 & NS & - & - & \\
\hline Sweetcrisp & 11.5 & 5.0 & * & 23.5 & 6.5 & * \\
\hline Vireo & 22.9 & 11.9 & * & - & - & \\
\hline
\end{tabular}

${ }^{2}$ Cross-pollination was performed with pollen from the selections FL11-037 and FL04-232 in 2012 and 2013, respectively.

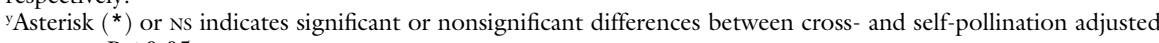
means at $P \leq 0.05$.

${ }^{x}$ Data not available.

decreasing compatibility with increasing relatedness (Darnell and Lyrene, 1989; Gupton, 1984). A common recommendation made for SHB growers is to interplant an unrelated cultivar as a pollen source. Wide variations occur in the cultivars used and the pollenizer density, to the extreme that many growers plant with alternating rows of different cultivars. However, nearly all cultural practices would be facilitated by the use of larger solid blocks of cultivars, as long as this strategy does not sacrifice earliness, fruit size, and yield.

Based on these observations, cross-pollination has the potential to improve yield through increased fruit set, decreased time to ripening and thus earlier harvesting, and increased seed number and fruit size. One notable exception among this group of cultivars was Farthing. 'Farthing' had similar or slightly higher fruit set after self-pollination in both years of the study. Additionally, developmental period differences between cross- and self-pollination were less than $5 \mathrm{~d}$ (Tables $\mathrm{l}$ and 2). The average fruit weight between crossand self-pollinated 'Farthing' fruit was not significantly different in 2012 , although there was a significant difference in seed number (Tables 3 and $6)$. This lack of negative impact following self-pollination may explain why 'Farthing' is consistently among the highest yielding of $\mathrm{SHB}$ cultivars.
However, based on the overall results presented here, interplanting at least two unrelated cultivars sharing a similar bloom period remains the best recommendation to achieve early, high yields among these SHB cultivars.

\section{Literature cited}

Aalders, L.E. and I.V. Hall. 1961. Pollen incompatibility and fruit set in lowbush blueberries. Can. J. Genet. Cytol. 3:300307.

Bailey, J.S. 1938. The pollination of the cultivated blueberry. Proc. Amer. Soc. Hort. Sci. 35:71-72.

Barker, W.G. and W.B. Collins. 1965. Parthenocarpic fruit set in the lowbush blueberry. Proc. Amer. Soc. Hort. Sci. 87:229-233.

Brewer, J.W. and R.C. Dobson. 1969 Seed count and berry size in relation to pollinator level and harvest date for the highbush blueberry, Vaccinium corymbosum. J. Econ. Entomol. 62:1353-1356.

Chavez, D.J. and P.M. Lyrene. 2009. Effects of self-pollination and cross-pollination of Vaccinium darrowii (Ericaceae) and other low-chill blueberries. HortScience 44:1538-1541.

Coville, F.V. 1921. Directions for blueberry culture. U.S. Dept. Agr. Bul. 974.

Darnell, R.L. and P.M. Lyrene. 1989. Cross-incompatibility of two related rabbiteye blueberry cultivars. HortScience 24:1017-1018.
Darrow, G.M. 1958. Seed number in blueberry fruits. Proc. Amer. Soc. Hort. Sci. 72:212-215.

Dogterom, M.H., M.L. Winston, and A. Mukai. 2000. Effect of pollen load size and source (self, outcross) on seed and fruit production in highbush blueberry cv. 'Bluecrop' (Vaccinium corymbosum; Ericaceae). Amer. J. Bot. 87:1584-1591.

Ehlenfeldt, M.K. 2001. Self- and crossfertility in recently released highbush blueberry cultivars. HortScience 36:133135 .

El-Agamy, S.Z.A., W.B. Sherman, and P.M. Lyrene. 1981. Fruit set and seed number from self- and cross-pollinated highbush $(4 \mathrm{x})$ and rabbiteye $(6 \mathrm{x})$ blueberries. J. Amer. Soc. Hort. Sci. 106:443-445.

El-Agamy, S.Z.A., W.B. Sherman, and P.M. Lyrene. 1982. Pollen incompatibility in blueberries (Vaccinium spp.). J. Palynol. 18:103-112.

Gupton, C.L. 1984. Effect of pollen source on fruit characteristics of lowchilling highbush type blueberries. HortScience 19:531-532.

Gupton, C.L. and J.M. Spiers. 1994. Interspecific and intraspecific pollination effects in rabbiteye and southern highbush blueberry. HortScience 29:324326.

Harrison, R.C., J.J. Luby, and P.D. Ascher. 1994. Fruit and seed set of half-high blueberry cultivars following repeated pollinations at varying time intervals. Fruit Var. J. 48:176-182.

Knight, R.J., Jr. and D.H. Scott. 1964. Effects of temperatures on self- and crosspollination and fruiting of four highbush blueberry varieties. Proc. Amer. Soc. Hort. Sci. 85:302-306.

Lang, G.A. and R.G. Danka. 1991. Honey-bee-mediated cross- versus selfpollination of 'Sharpblue' blueberry increases fruit size and hastens ripening. J. Amer. Soc. Hort. Sci. 116:770-773.

Lyrene, P.M. 1989. Pollen source influences fruiting of 'Sharpblue' blueberry. J. Amer. Soc. Hort. Sci. 114:995-999.

Lyrene, P.M. and R.G. Goldy. 1983. Cultivar variation in fruit set and number of flowers per cluster in rabbiteye blueberry. HortScience 18:228-229.

MacKenzie, K.E. 1997. Pollination requirements of three highbush blueberry (Vaccinium corymbosum L.) cultivars. J. Amer. Soc. Hort. Sci. 122:891-896.

Meader, E.M. and G.M. Darrow. 1944. Pollination of the rabbiteye blueberry and related species. Proc. Amer. Soc. Hort. Sci. 45:267-274. 
Meader, E.M. and G.M. Darrow. 1947. Highbush blueberry pollination experiments. Proc. Amer. Soc. Hort. Sci. 49:196-204.

Miller, S., P. Alspach, J. Scalzo, and J. Meekings. 2011. Pollination of 'Hortblue Petite' blueberry: Evidence of metaxenia in a new ornamental homegarden cultivar. HortScience 46:14681471 .

Moore, J.N., B.D. Reynolds, and G.R. Brown. 1972. Effects of seed number, size, and development on fruit size of cultivated blueberries. HortScience 7:268-269.

Morrow, E.B. 1943. Some effects of cross-pollination versus self-pollination in the cultivated blueberry. Proc. Amer. Soc. Hort. Sci. 42:469-472.

Payne, J.A., A.A. Amis, J.H. Cane, and P.M. Lyrene. 1989. Fruit size, seed size, seed viability and pollination of rabbiteye blueberries (Vaccinium ashei Reade). Acta Hort. 241:38-43.

Rabaey, A. and J. Luby. 1988. Fruit set in half-high blueberry genotypes following self and cross pollination. Fruit Var. J. 42:126-129.

White, E. and J.H. Clark. 1939. Some results of self-pollination of the highbush blueberry at Whitesbog, New Jersey. Proc. Amer. Soc. Hort. Sci. 36:305-309.

Williamson, J.G., J.W. Olmstead, and P.M. Lyrene. 2015. Reproductive Growth and Development of Blueberry. 30 June 2015. $<$ https://edis.ifas.ufl.edu/hs220>.

Wood, G.W. 1968. Self-fertility in the lowbush blueberry. Can. J. Plant Sci. 48:431-433. 